\title{
Poverty, Inequalities and the Perceptions on Distributive Justice
}

\author{
Munawar Iqbal \\ Professor, Islamic Economics Institute, King Abdulaziz University, Jeddah
}

\begin{abstract}
Distributive justice may mean different things to various schools of thought. Active discussions on poverty and inequality are among economic debates which have been going on for a long time. However, during the last fifty years, they have received a lot more attention by both academicians and policy makers. Fifty years ago, growth in national income was considered to be the most effective way of reducing poverty and was the preferred policy goal even at the cost of increasing inequalities. Perspectives on both poverty and inequality have changed over time. The very definitions of poverty have been revised. Poverty is now seen as having many manifestations. Money income is not the only factor to determine who is poor, though it remains an important element. In this paper, we discuss the issues involved in this debate and present different views on distributive justice. The Islamic perspective on distributive justice and the strategy to achieve it is given special attention.
\end{abstract}

Keywords: Distributive justice, Inequality, Poverty alleviation, Multi-dimensional poverty, Social safety nets.

KAUJIE Classification: N2, N3, N4, N7.

\section{Introduction}

That poverty is a multi-dimensional and multifaceted phenomenon is almost universally agreed. However, some of the manifestations of inequality have been over-riding concerns more than others. In particular, income inequalities (and poverty) have been and remain the focus of all debates on the issue, as well as the major target of most policy initiatives. The emphasis on income and wealth inequalities is neither surprising nor out of place. In our view, Islamic economic teachings have also placed more emphasis on addressing income in-equalities and poverty alleviation than the other types of deprivations and there are sound reasons for that. We will explain those in this paper.

In the main contribution to this discussion forum, Zaman (2018) states: 
We sketch a three-dimensional approach to resolving problems created by inequalities and poverty, based on spiritual, social, and institutional components. In each area, the source materials of Islam and Islamic history provide ample guidance and precedent for a radically different approach to these problems. (p. 69)

While he makes a very useful contribution in sketching the three-dimensional approach, his references from Islamic sources may not be well-stated. The general tenor of his argument may be right but on some matters, it is either subject to misunderstanding or is incomplete. On certain points, he may have overstated the case which may cause misapprehension about the Islamic viewpoint on the matter. In this paper, we attempt to address these issues so as to present the Islamic perspective on poverty, inequality, and distributive justice in clearer terms. We would like to begin by stating some general rules relating to the subject under discussion from an Islamic perspective.

\section{The Divine Rule of $a b$-initio Unequal Distribution}

Income and wealth are among the countless bounties of Allah Almighty on mankind. In the distribution of all these bounties, inequality is the rule. There are many texts in the Holy Qur'ān and ahādith of Prophet Muhammad (may the peace and blessings of Allah be upon him) that testify to this rule. The two most important bounties of Allah Almighty after "righteousness" (in belief and deeds) are wealth and children. Qur'ān mentions the rule of $a b$ initio inequality with respect to income/wealth in the following words:

Is it they who allocate the mercy of your Lord? We have allocated among them their livelihood in the worldly life, and have raised some of them over others in ranks, so that some of them may put some others to work. And the mercy of your Lord is much better than what they accumulate. (Qur'ān, 43:32)

With respect to the other most important blessing of Allah Almighty, children, He states:

To Allah belongs the kingdom of the heavens and the earth. He creates what $\mathrm{He}$ wills. He grants females to whom He wills, and grants males to whom $\mathrm{He}$ wills. Or He combines for them couples, both males and females, and makes whom He wills barren. Surely, He is All-Knowing, Very-Powerful. (Qur'ān, 42:49-50)
Human history and observation also affirm unequal distribution of almost all bounties of Allah Almighty. Some persons have been given more wealth than others $^{(1)}$; some have better physical power than others. Some are born more intelligent than others by virtue of their genes. Some are born with "a silver spoon in their mouth" as the English idiom states. All of these bounties of Allah Almighty are a test. One will have to account for these on the Day of Judgment. Hence, Zaman is right in stating that these inequalities have a 'purpose' in the grand design of Allah Almighty, i.e., allowing some to take work from others and create mutual dependencies in society. However, some of these inequalities are subject to human intervention and some are not. Among those which are subject to such intervention, income and wealth inequalities are on the top of the list.

\subsection{The Special Nature of Income and Wealth Inequalities}

When we review Islamic nuṣūṣ (texts from Qur'ān and Sunnah), we find that though Islamic teachings provide guidance for removing all deprivations; inequalities of income/wealth and means to redress them get a lot more attention than other kinds of deprivations. In our understanding, there are two main reasons for that:

(1) Income and wealth inequalities apparently have more human input, and man tends to consider that these are the result of his own "doings". The rendering of the example of one of the wealthiest persons in human history, Qaroon, given in the Qur'ān makes this apprehension very clear.

Indeed Qaroon was from the people of Musa, then he rebelled against them. And We had given to him such treasures as their keys would weigh too heavy for a strong group of people. (Remember) when his people said to him: do not exult. Surely, Allah does not like the exultant. And seek the (betterment of) the Ultimate Abode with what Allah has given to you, and do not neglect your share from this world, and do good as Allah did good to you, and do not seek to make mischief in the land. Surely, Allah does not like the mischief-makers. He said: I have been given this only on account of the knowledge I have. Did he not know that Allah had destroyed

(1) Even though an individual has to work for it but he gets only what has been apportioned for him by Allah Almighty, and he uses abilities given by Him to earn it. 
before him of the generations those who were mightier in strength than he and greater in assemblage? And the guilty shall not be asked about their faults. (Qur'ān, 28:76-78)

Another verse of the Qur'ān states this in a very sophisticated manner. Allah Almighty says:

Do not kill your children for fear of poverty. We provide sustenance to them and to you, too. Killing them is a great sin indeed. (Qur'ān, 17:31)

The verse is immaculately phrased. Allah Almighty first says that "do not kill your children for fear of poverty. We provide sustenance to them". He reminds people that though apparently, you provide sustenance to your children but actually $W e$ do that. But $\mathrm{He}$ does not stop there. He further reminds people that no one should think that his income and wealth is "due" to his own efforts. It is Allah Almighty who provides sustenance to them also. Their input should not make them forget that reality.

(2) Income and wealth can be redistributed either voluntarily by the "possessor"(2) or by legal injunctions. Examples of the former are various kinds of charitable donations and of the later various redistributive taxes in the conventional system and zakāh and some other levies in the Islamic system.

As against these, most other bounties of Allah Almighty cannot be redistributed (alienated). For example, one cannot alienate his intelligence nor can the government tax it.

To conclude, we will quote one more hadith in support of our argument that redressing income and wealth inequalities are priority areas and need special attention.

Ibn Masood reported that Prophet (may the peace and blessings of Allah be upon him) said: No man will be allowed to move his feet from Allah's front (His Court) until he answers five questions (i) In what (sort of acts) did he spend his life; (ii) What did he achieve (good or bad) during his youth; (iii) How did he earn his wealth; (iv) On what did he spend his wealth; (v) How much he acted upon what he learnt. (al-Tirmidhi, 1975, 4:612, hadith no. 2417)

It is pertinent to note that 2 out of 5 of these questions $(40 \%)$ relate to wealth.

(2) We use the word "possessor" rather than owner to signify that the "real" owner of wealth is Allah Almighty as also mentioned by Zaman.

\subsection{Interaction between Inequalities and the Islamic Approach to their Control}

Inequalities get more serious because there are interactions between economic, social, and cultural inequalities. We cannot delve into this issue in detail here due to space limitations. One example should be enough to make our point. Money begets power (political or social) and power begets money. Quoting from (Polanyi, 1944), Zaman (2018) relates the situation created by the so-called "Great Transformation" wherein the political circumstances "led to a massive landgrab by the aristocracy, 'a revolution of the rich against the poor', in the form of enclosures, which turned vast areas of land into the private property of the rich" (p. 72). This kind of situation is unimaginable in a truly Islamic state. The political and social power class structure is alien to Islam. Islam grants an individual, rich or poor, ruler or ruled, belonging to the so-called bourgeois class or a peasant, equal rights and social respect. The Holy Qur'ān emphatically stamps out such class-structure as being any source of pride or privilege.

O mankind, We have created you from a male and a female, and made you into races and tribes, so that you may identify one another. Surely the noblest of you, in Allah's sight, is the one who is most pious of you. Surely Allah is All-Knowing, All-Aware. (Qur'ān, 49:13)

Prophet Muhammad (may the peace and blessings of Allah be upon him) also stated in his Last Address:

O People! your Allah is One. Your father is One. Beware! There is no preference for an Arab over a non-Arab; nor for a non-Arab over an Arab. Nor for a black-colored over a red-colored; nor for a redcolored over a black-colored: except by piety. (alShaibani, 2001, 38:474, hadīth no. 23489)

There are numerous examples that during the early period of Islamic history, which is the true representation of Islamic institutional and social fabric of the society, that the social and political power could not be a source of any privilege. That breaks the chain leading from political or social power to accumulating wealth. One major source of income of wealth inequalities in secular economies is thus broken at the root. 


\section{The Divine Rule of Accountability}

The Islamic belief in the Day of Judgment when one has to account for everything, big or small, good deeds and bad deeds, is the engine that turns Allah Almighty's bounties into responsibilities and the lack of them tolerable. This Divine Rule is stated in the Qur'ān and hadīth scores of times. Verse (43:32) quoted by Zaman is important but the crunch is perhaps best expressed in the following verses:

So, whoever does any good act (even) to the weight of a particle will see it. And whoever does evil (even) to the weight of a particle will see it. (Qur'ān, 99:7-8)

The belief in the Rule of Accountability turns worldly bounties into responsibilities. The more a person fears Allah Almighty, the more heavily he feels the "burden" of these bounties. One of the tābi inn reported that the first Caliph, Abu Bakr (one of the wealthy individuals in his time) said:

Zahhak reported that Abu Bakr (may Allah be pleased with him) saw a bird sitting on a tree and exclaimed: "O bird, glad tidings for you. You fly and then sit on a tree. Then eat of its fruit and fly again. There is neither accountability nor any torment for you. I wish I were like you". (alBayhaqi, 2003, 2:227, hadith no. 768)

Similar yearnings have been reported for Omar (may Allah be pleased with him) the second caliph and other companions.

Zaman's reading of Islamic literature as being paradoxically supporting both viewpoints: the premodern view of poverty as honorable and wealth as evil, as well as the opposite view of poverty as evil and wealth as a blessing, needs some clarifications. His stance may not be incorrect. However, it is not stated well. The Islamic position needs to be explainned better in order to avoid any misunderstanding.

Poverty is never seen as honorable. Poor as stated above are as respectable as anyone else in the society. However, poverty is "endured" as long as it cannot be alleviated by the individual, society, or the state. In a hadith Prophet Muhammad (may the peace and blessings of Allah be upon him) spoke against poverty in the following words:

Anas bin Maalik reported that the Prophet (may the peace and blessings of Allah be upon him) said:
Poverty may lean (one) towards disbelief ${ }^{(3)}$. (alBayhaqi, 2003, 9:12, hadīth no. 6188)

It is to be noted that some scholars think this hadith to be weak. However, the undesirability of being in the state of poverty is confirmed by the fact that the Prophet (may the peace and blessings of Allah be upon him) used to regularly pray:

O Allah, I seek your refuge from disbelief and poverty; and from the torment of the grave. (alNasai, 1986, 3:73, hadīth no. 1347)

Wealth is also not considered an evil in itself. It is a blessing of Allah Almighty. The use of wealth can be in evil ways, but so can be the case with all other bounties of Allah Almighty. The phrasing of verse (43:32) of the Qur'ān is very illuminating and is worth a comment. The verse as translated reads:

Is it they who allocate the mercy of your Lord? We have allocated among them their livelihood in the worldly life, and have raised some of them over others in ranks, so that some of them may put some others to work. And the mercy of your Lord is much better than what they accumulate. (Qur'ān, 43:32)

The verse opens with Allah Almighty's authority to distribute his mercy; then quotes livelihood as an example of his mercy; states the Rule of $a b$ initio unequal distribution in his bounties and the wisdom behind it, and then concludes: Allah Almighty's mercy is much better than accumulating wealth, clearly implying that wealth is better used to seek Allah Almighty's mercy on the Day of Judgment.

The belief in the Divine Rule of Accountability turns both poverty (or for that matter any suffering) and abundance (or any state of bliss) as equally rewarding.

Suhaib (may Allah be pleased with him) reports that Prophet Muhammad (may the peace and blessings of Allah be upon him) said: The position of a true believer is unique. All states of affairs are good for him. And this is not the case except for a true believer. If he gets happiness, he thanks (Allah Almighty) and that gets him a reward. And if he is struck by a distress; he remains patient and that gets him a reward. (al-Naisabouri, 1991, 2:2295, hadìth no. 2999)

(3) The meaning of the hadith (Allah knows best) is that the state of extreme distress may become so unbearable that one may lose faith in Allah Almighty's authority to remove his distress. 


\section{Distributive Justice}

It is important to make a distinction between the functional distribution of income and personal distribution of income. Inequalities in both may exist and are acceptable in an Islamic framework. The functional distribution of income relates to input pricing. In the conventional paradigm, these are determined in free markets according to the forces of demand and supply. The dominant view is the rule that each factor is entitled to the value of its marginal product. This pricing, of course, takes place in the input markets (and for labor in labor markets). Here again, Zaman makes some remarks that may be imprecise in understanding the Islamic position. His tirade against a market society has an emotional tinge. To state that "the market society requires a labor market which dehumanizes people turning them into commodities" (p. 69) is an emotive statement. The Islamic economic system has free markets as one of its essential components. Rather, it ensures the free and fair functioning of markets by a special institution called "hisbah" or "market inspection". Prophet Muhammad (may the peace and blessings of Allah be upon him) used to visit markets on a regular basis to ensure their proper functioning. Two ahädith in this respect would be enough to clear the Islamic view of the market.

Abdallah ibn Omar (may Allah be pleased with him) reported that Prophet Muhammad (may the peace and blessings of Allah be upon him) said: Do not offer to buy (at a higher price) if someone has concluded a purchase and do not reach out for a commodity until it reaches the market. (al-Bukhari, 1422H, 3:72-72, hadīth no. 2165)

The second is a famous hadith which states:

Whoever cheated us, is not from us (i.e., is not a true believer). (al-Naisabouri, 1991, 1:99, hadīth no. 102)

This hadìth is so important that it is considered as one of the guiding principles in trading and other exchange contracts and is very widely quoted.

Another guiding principle in this respect is that prices should be left to be determined by the forces of supply and demand, unless there is a case of "market failure" or other apparent violation of rules of fair play leading to exploitation of one of the parties. It is only then that the government can and should intervene in pricing. This rule emerges from another hadīth:
Anas (may Allah be pleased with him) reported that during the period of Prophet Muhammad (may the peace and blessings of Allah be upon him) prices increased. Companions approached him requesting imposing price controls. On that, the Prophet (may the peace and blessings of Allah be upon him) said: Allah is the controller; the enlarger (of provisions); the provider of sustenance and the price-fixer. I wish to meet Allah (in a situation) that no one lays any claims against me for being unjust to him with respect to his life or wealth. (Abu Dawood, 2009, 5:322, hadìth no. 3451; al-Tirmidhi, 1975, 3:597, hadith no. 1314)

Islamic scholars sometimes take this hadith as a rule against market intervention by governments. That can be taken as a general rule. However, if there are violations of fair practices, then the government can and must intervene. In this respect, the ruling of Ibn Taymiyyah is very enlightening. He explains the limits of government intervention in price fixation (or on analogy; of general government intervention in the markets) in the following words:

As for [fixing] prices, some of it [in some cases] involves injustice and, hence, is not allowed while some of it [in some cases] is just and, hence, is allowed. If it involves injustice to people by forcing them - without any right - to sell on prices that they do not agree to or prohibiting them from something that Allah has made lawful for them; then it is harām. If it involves maintaining justice between the people like forcing them to do what is obligatory upon them, that is, to transact on the basis of 'thaman al-mithl' [market price of the commodity or of its closest substitute] and preventing them from what is prohibited like taking higher compensation than 'thaman al-mithl', then it is allowed. Rather, it is a must. . . If people are buying and selling according to the established practices without any unjust practice from them and the prices rise; either due to a shortage in supply or due to more demand; that is Allah's bidding. Forcing people to sell at a specific price is unjust. However, if despite people's need, the sellers refuse to sell except on a price higher than customary prices; then they must be required to sell on 'thaman al-mithl' basis. Hence, price-fixation is nothing but ordering them to sell on the basis of 'thaman al-mithl' and imposing what Allah has imposed on them [i.e., justice]. (Ibn Taymiyyah, n.d., p. 22) 
In the case of labor, Zaman is not the only one to give it a special position. Indeed, in the socialistic system, labor is considered to be the sole medium for the creation of 'surplus value'. In the capitalistic system, and also under the so-called 'welfare state' paradigm, the government imposes minimum wage laws and, in addition, taxes the rich to provide essential services to the poor in terms of "social safety nets". In recent years, the provision of these services (e.g., health, education) from government revenue has become an area of hot debate. It was one of the major issues in the last US presidential elections with the Republicans and Democrats arguing about the extent of such support and the resource mobilization options for their provision. The academic debate on distributive justice has also concentrated on the justifiability, objective, and the resource mobilization mechanisms. We will briefly touch on this issue in the next section.

Before closing the discussion on functional income distribution, we would like to comment on two factor returns: labor and capital. Some people think that the egalitarian approach of Islam favors minimum wage laws. In our view that is not the case. Wage is an 'input price', like any other input price. The same rules mentioned above, (i.e., non-government intervention) apply to wage determination, unless there is a case of unfair play or exploitation. If an employer pays a worker wages equal to his marketdetermined marginal revenue product, he has done justice. If the total income of a person, due to whatever reasons, is not enough to fulfill his minimum basic needs, it falls in the area of personal income distribution. The Islamic system treats it by a large number of re-distributive measures ${ }^{(4)}$.

The return to capital as an input is another issue of relevance. In the conventional system, it is determined by the market as the rate of interest. The Islamic prohibition of rib $\bar{a}$ (usury) has important implications for distributive justice. A natural consequence of interest-based lending is that the financial resources flow mainly to the rich. Chapra (2001) provides a good explanation as to how that happens.

Financial intermediation on the basis of interest tends to allocate financial resources among borrowers primarily on the basis of their having

(4) For a very good treatment of these redistributive measures, please see, Zarqa, M. Anas, 1988. acceptable collateral to guarantee the repayment of principal and sufficient cash flow to service the debt. End-use of financial resources does not constitute the main criterion. Even though collateral and cash flow are both indispensable for ensuring repayment of loans, giving them undue weight leads to a relative disre-gard of the purpose for which borrowing takes place. Hence, financial resources go mainly to the rich, who have the collateral as well as the cash flow, and to governments, who, it is assumed, will not go bankrupt. However, the rich borrow not only for productive investment but also for conspicuous consumption and speculation, while the governments borrow not only for development and public well-being, but also for chauvinistic defense buildup and white elephant projects. This does not only accentuate macroeconomic and external imbalances, but also squeezes the resources available for need fulfillment and development. (p. 3-4)

\section{Redistribution of Income, Wealth and Public Revenues}

Once free and fair market force have allocated incomes to individuals, some are better off than others. Some people, especially the disabled, are not able to meet their minimum basic needs. Here the role of 'society' comes in to play. In any civilized society, people who are needy must be supported. The question is whom, how much, and from where? There is a lot of debate about this issue in conventional literature. In brief, there are two major schools of thought: the "egalitarian" school of distributive justice and the "utilitarian" school of distributive justice. The 'objective' of the egalitarian school is 'welfare equalization' while the objective that the utilitarian school pursues is 'welfare maximization'. Thus, the egalitarian school would recommend allocation of government revenue reserved for public support to help those who are worst off in terms of welfare trying to 'equalize' welfare. As against this, the utilitarian school would allocate resources to those who can benefit from them most, i.e., who will maximize total welfare in the society. Thus, as an extreme example, the utilitarian approach would allocate lesser resources to the disabled since they may not be able to use those resources to create as much total welfare in the society as able-bodied persons would ${ }^{(5)}$.

(5) For a good analysis of this debate, see Mark S. Stein (2006). 
As for the Islamic position on distributive justice, it can be summarized in the following three points:

1. Guarantee of fulfillment of the basic needs of all.

2. Equity but not equality in personal incomes.

3. Elimination of extreme inequalities in personal income and wealth.

There is general agreement among Islamic economists that fulfillment of the basic needs of all is one of the most important objectives of Islamic distributive justice. However, in what way the basic needs are to be catered for is a question that is subject to some debate. Three misconceptions found in Islamic economic literature must be removed.

One, it should be understood that provision of basic needs is not the responsibility of the Islamic government. It is the Islamic system's working as a whole that would ensure that. If due to any reason that does not happen, then the government would provide support to the needy subject to the qualification that enough resources are available in the public exchequer. If enough public resources are not available, then the government is not obliged to provide monetary support for meeting the needs of the poor. Rather, the role of the government would be to take steps to correct "moral failure" that prevented the built-in systemic arrangements from functioning properly. Zaman's statement that: "if resources are inadequate to meet all the needs, then the community must prioritize according to the guidelines prescribed by the Sharī'ah" (p. 82) is correct. But the guidelines prescribed by the Sharīah do not require what he goes on to say: "As a last resort, a community may pool its resources and share them equally" (p. 82). Sharing resources equally in a special situation and temporarily may be an option that an Islamic government may use, but this is not to be considered a permanent arrangement.

The second misconception is that the zakāh system, if properly implemented by the state, will eradicate poverty or at least meet the basic needs of all. In fact, that is not the case. Zakāh is the 'minimum' that an individual has to contribute towards meeting some societal needs, poverty alleviation being the most important, but not the only one. The proceeds of $z a k \bar{a} h$ will most often fall short of the needs of the poor. As a matter of fact, zakāh proceeds alone have never been sufficient to fulfill basic needs.
Third, examples from Islamic history, such as the period of the second Caliph Omar (may Allah be pleased with him), wherein there were wide-ranging public support schemes in operation, should be quoted with caution. It must be noted that most of the sources of revenue of bayt al-māl (public treasury) at that time, such as ghana 'im (war booty acquired after fighting), fay' (booty acquired without actual fighting), kharāj (land tax; initially imposed by Caliph Omar on conquered lands), and jizyah (poll tax imposed on non-Muslim citizens of an Islamic state against protection granted to them), are not available to contemporary Muslim states. Hence, eulogizing the Islamic historical examples should not blind us of the stark reality that the public exchequer in most of the contemporary states cannot meet even a small fraction of the needs of the poor segments of society. We must look towards many other redistributive schemes which have great potential for poverty reduction but are dormant in contemporary Islamic history.

Zaman's emphasis on free education as a vehicle of equal opportunity and hence a priority policy for the fight against poverty is well-taken. However, quoting Shalaby's (1954) tributes and 'stopping' without further comment at statements like "since providing education to the young is a collective responsibility of the society, there was no concept of charging money for this. For all who desired it, education was freely available" (Zaman, 2018, p. 83) is idealistic. Islam had marvelous historical examples in all fields during its Golden Era. Remembering those as ideals to strive for is virtuous. However, a pragmatic approach would require taking note of present realities. Equal opportunity and free education are two different objectives. The first is much easier to attain. However, in a contemporary situation, provision of free education is a far cry. Most Muslim states allocate less than $2 \%$ of their annual budgets to social sectors of health and education. Even if they were able to quadruple that ratio, the provision of free education to all who desired it would be a dream not to come true (in the foreseeable future).

Zaman is right in stating that "the provision of basic needs to all is the collective responsibility of the ummah as a whole" (p. 80). Even in today's national states structure, there is a hierarchy of responsibilities, running from the individual himself to the neighborhood, society at large, and the government 
as the final recourse. Islam has a very comprehensive system for achieving its goals of distributive justice. It is these "systemic" arrangements that will cater to the basic needs of all on the one hand, and keep income and wealth inequalities within acceptable limits on the other. Zarqa (1988) counts some 26 different redistributive schemes that are part and parcel of the Islamic system.

As stated in Iqbal (1988), having ensured the fulfillment of the basic needs of all, Islam permits interpersonal differences in income. This derives from the Islamic view of justice to all. In view of natural differences in human talent and capacity, it would be unjust to equate all people in terms of their earnings while they are different in terms of their abilities and contribute different amounts to the production process. It is unjust, as well as inefficient. It would kill individual incentive and would be detrimental to productive efficiency. It would lead either to lethargy and inactivity on the part of recipeents or to compulsion and coercion on taxpayers; both of which are abhorred by Islam while these are major problems facing contemporary welfare states.

Once it is understood that distributional justice does not mean, rather rules out, perfect equalities of income, one faces the question of the optimal level of inequality. Islam does not prescribe a ratio between the minimum and the maximum income but discourages extreme inequalities. The purpose is not to establish justice alone but to promote mutual love and kindness as well. Glaring disparities in income and wealth lead to social and political disruption, while Islam stands for social cohesion, mutual love, and brotherhood. Therefore, those inequalities which can cause hatred, malice, and ill-feeling among individuals should be eliminated.

In the Islamic system, the possibility of extreme inequalities is minimized, in the first place, by eliminating all sorts of exploitative practices, such as rib $\bar{a}$, ghish, akl al-māl bi al-bātill, etc. After that, Islam uses a two-way policy to reduce inequalities and promote social cohesion. On the one hand, it advises people not to bear a grudge against someone who has more than others and, on the other hand, it prescribes a number of measures to transfer wealth from the rich to the poor. One of the important features of the Islamic measures of redistribution is that it minimizes the negative effect on individual incentives. The giver derives positive utility and enjoys rather than resents sharing his income and wealth with others.

The salient features of the Islamic strategy for removing undesirable inequalities in income and wealth and achieving the desired pattern of distribution may be described as follows:

a) Islam utilizes an "institutional approach" in its distributive scheme. The market, as an institution, is allowed to play a significant role. It is, however, supplemented by other institutional arrangements to correct some inbuilt tendencies in the market solution which may generate excessive inequalities. These institutions include awqāf, manĭhah, strict rules of inheritance ${ }^{(6)}$, the elimination of interest, etc.

b) Islam prefers a decentralized structure of redistributive measures. It requires one to look after the needs of his near relatives, his neighbors, his locality and then society at large, in that order. This approach has very important economic and social implications. From an economic point of view, it minimizes the disincentive effects on both the donor and the recipient. When a person is spending his money (or observes it being spent) on his near relatives and neighbors and sees how it helps reduce their misery, he does not feel the disincentive effects that a person feels when he is subjected to a high rate of progressive tax (even though that money is spent somewhere to relieve similar misery). For the same reason, such a scheme reduces the problem of tax evasion and avoidance. Similarly, the recipient cannot become a parasite on public funds, because in a localized arrangement his real circumstances and attitudes are known to the donors who can use social pressure to get him to work and provide the necessary means for him to do so. Both of these (evasion for the givers and parasitic attitude for the recipients) are serious problems that the contemporary welfare states are grappling with. In his classic book, Equality and Efficiency: The Big Tradeoff, Okun, uses a "leaky bucket" metaphor to state that some of the money taken from the

(6) Like the rules of zakāh, these rules cannot be changed by any government. 
rich in a re-distributive program will leak out and will not reach the poor. What the metaphor implies is that on the one hand, higher tax rates on the rich increase their incentive to use tax avoidance loopholes (leaks). On the other hand, higher support for the poor reduces their incentive to work. If going to work adds only a small amount to the household income as compared to the bundle of safety-net receipts, many lower-income families would work less than they otherwise might.

c) Islam uses a multiplicity of redistributive measures. Each one of them, taken alone, may appear to be small but their combined effect implies a substantial transfer. This again has a number of economic advantages. On the one hand, it reaches every category of deserving recipient. Again, the minimal incidence of each one of them reduces the negative effects. Many of them do not involve any cost to the donor but increase the marginal utility of the recipient substantially. An example of these measures is allowing someone to temporarily benefit from the usufruct of assets not currently used by the owner.

d) Islam uses a hierarchy of compulsory and voluntary, permanent and temporary, measures which lend flexibility to the system. Some of the schemes, such as zakāh, participation in the ownership of some natural resources, and the system of inheritance, are permanent and compulsory. There are some measures such as charity and $a w q \bar{a} f$ (trusts) which are voluntary.

e) Redistributive measures are no doubt important in the Islamic strategy for achieving the desirable pattern of distribution but, in my view, they have been over-emphasized in the literature of Islamic economics to the neglect of some other basic measures. The distinction between exchange and transfer as a means of distribution is very important in this respect. The Islamic strategy relies on measures which work through exchange as much as, if not more than, the measures which involve transfers. Unfortunately, the distributional implications of the Islamic rules governing market exchange have not been analyzed properly. Measures such as the prohibition of interest, the promotion of profit sharing, discouraging monopolies, correcting ownership patterns, the equality of opportunities, the emphasis on employment and work, the prohibition of certain trade practices, etc., have direct implications for the Islamic distributive standards.

\section{Alternative Measures of Poverty and Inequality}

Traditionally, poverty is measured by reference to the annual income of a household. There are two types of measures which are popularly used. Absolute poverty is measured by reference to the cost of a basket of goods and services considered to be basic needs. People having less income than that are considered poor. The most famous is the one that was developed by the World Bank in 1990. In this measure, the absolute measure of income needed for meeting some basic needs is used to define a 'poverty line'. For global comparisons, the purchasing power parity is used. At that time (1990), the poverty line was determined to be $\$ 1$ a day. It was estimated that 1.25 billion people in the world were living below the poverty line. Since then, poverty alleviation has been the most important policy goal pursued by the World Bank. In 2000, the UN issued Millennium Development Goals (MDGs) the major focus of which was poverty reduction. In the next few years, there was considerable progress at the global level with the number of poor reduced to half by 2010 , five years ahead of the target. Nearly 1.1 billion people have moved out of extreme poverty since 1990 . However, these averages conceal regional disparities with a large number of countries recording much less reduction in poverty. The averages were pulled up mainly by growth in East Asia and Pacific while SubSaharan Africa still suffers from the worst rates of poverty. In 2013, half of the extremely poor lived in Sub-Saharan Africa. The number of people living on less than $\$ 1.90$ (the new PPP adjusted poverty line) in this region was 389 million; more than all other regions combined ${ }^{(7)}$.

OECD defines the poverty line as half the median household income of the total population. National governments measure poverty differently but mostly based on household income. In the U.S., the Census Bureau determines 'poverty thresholds' every year. These are based on family income and 'thresholds'

(7) See, http://www.worldbank.org/en/topic/poverty/overview; and Roser and Ortiz-Ospina (2017, p. 4-6). 
are determined based on family size and number of children below 18. In Europe, the main poverty indicator is relative income. The European Commission issues "at-risk-of-poverty" rates. These are defined as households having a percentage of national median income. At-poverty-risk rates for $40 \%, 50 \%, 60 \%$ and $70 \%$ of national median income are measured. The $60 \%$ threshold is used for most policy purposes.

Inequality measures supplement the poverty-line based measures for discussion on distributive justice. The Gini coefficient and the Lorenz curve are textbook statistics of inequality. Some measures of inequality of 'public' interest are also regularly reported. The two most commonly quoted measures are the S80-S20 Quintile Ratio and the Palma Ratio. The first is defined as the average income of the richest $20 \%$ of the population to the average income of the poorest $20 \%$ of the population. The Palma Ratio is the ratio of the richest $10 \%$ of the population's share of gross national income divided by the poorest $40 \%$ 's share. In fact, the Palma ratio is an alternative to the Gini index. It addresses the oversensitivity of the Gini index to changes in the middle of the distribution and insensitivity to changes at the top and bottom.

Let us look at some statistics to give an 'on the ground' flavor of inequalities. Statistics released by Eurostat show that in 2015 a population-weighted average of national figures for each of the individual EU member states indicated that the top $20 \%$ of the population received 5.2 times as much income as the bottom $20 \%$. Another source gave the following figures for some selected countries.

In recent years there have been some concerns about inequality measures based only on income or wealth. Some alternative measures have started being prepared. For example, the United Nations Sustainable Development Solutions Network is preparing a Happiness Index to rank countries since 2012 and is published in "The Happiness Report". The Index is based on six key factors: (i) Income (ii) freedom (iii) generosity (iv) health (v) social support and (vi) trustworthy governance.
Table 1: Share of Total Income Held by the Highest Ten Percent (2016)

\begin{tabular}{|c|c|}
\hline \multicolumn{1}{|c|}{ Ten Percent (2016) } & Percentage \\
\hline Country & 32.0 \\
\hline Russia & 31.7 \\
\hline United Kingdom & 29.9 \\
\hline United State & 28.5 \\
\hline Italy & 26.8 \\
\hline France & 25.1 \\
\hline Canada & 22.1 \\
\hline Japan & 21.7 \\
\hline
\end{tabular}

Source: Statista

\subsection{Inequality across Gender and Ethnic Groups}

Other serious issues in the debate on distributive justice are the dimensions of gender and ethnic inequalities (discriminations). These are socially more serious matters. Though, over time, these disparities have somewhat decreased due to greater awareness and social pressure, but they are still serious concerns. Many social groups are active against these and report such inequalities. Official sources have also started giving these matters special attention in policy formulation.

In 2015 , in the UK, around $40 \%$ of the people from ethnic minorities were in income poverty; twice the rate for white people. The income poverty rate varies substantially between ethnic groups: Bangladeshis (65 per cent), Pakistanis (55 per cent) and black Africans (45 per cent) have the highest rates, while black Caribbeans (30 per cent), Indians ( 25 per cent), white other ( 25 per cent) and white British (20 per cent) have the lowest rates (Kenway, \& Palmer, 2007, p. 5).

According to the American Community Survey (2007-2011) conducted by the U.S. Census Bureau, while the national average poverty rate was $14.3 \%$, for Hispanics it was $22.3 \%$ and for American Indians, it was as high as $27.0 \%$. The poverty rate for Whites was just $11.2 \%$. In Canada, the National Council of Welfare Census (2006) showed that the overall poverty rate in Canada was $11 \%$. But for racialized persons, it was $22 \%$, compared to $9 \%$ for nonracialized persons. 
Table 2: Wage Gap in Selected Countries (2015)

\begin{tabular}{|c|c|}
\hline Country & Percentage \\
\hline Australia & 13.00 \\
\hline Austria & 17.04 \\
\hline Canada & 18.63 \\
\hline Denmark & 5.84 \\
\hline Finland & 18.06 \\
\hline Greece & 6.25 \\
\hline Ireland & 14.45 \\
\hline Japan & 25.73 \\
\hline Korea & 37.18 \\
\hline New Zealand & 7.92 \\
\hline Norway & 7.12 \\
\hline UK & 17.10 \\
\hline USA & 18.88 \\
\hline
\end{tabular}

Source: OECD

With respect to gender inequalities, there is a lot of discussion about the "Gender Wage Gap". Most statistics show that women are paid less than men for similar work. Though, due to the efforts of women activists, the gap has narrowed in recent years but it is still noticeable despite the enforcement of equal pay acts in several countries. According to the American Association of University Women (AAUW), more than 50 years after the "Equal Pay Act" was passed in 1963 , women still receive about $79 \%$ of what men earn in similar jobs. Ethnicity plays a role here too.
Black and Hispanic women are most affected by the wage gap. According to the U.S. Census Bureau statistics, white women receive $75 \%$ of what white men receive, but black women receive $60 \%$ and Hispanic women receive only $55 \%$ for similar work. Table 2 presents data on the gender wage gap ${ }^{(8)}$ in 2015 in selected countries.

\section{Conclusion}

Poverty and income inequalities have been with humanity since the beginning of time and will remain with us until the end of time. The objective of human effort should be to make them 'palatable'. Justice to all is the key. However, perspectives on justice differ among scholars, societies and states. These perspectives change over time. In this paper, we have attempted to explain the Islamic perspective and to show that Islamic rules in the area of income and wealth distribution can go a long way to keep income inequalities in check and to make those that remain less painful. The Islamic belief in the life hereafter, on the one hand, makes poverty 'endurable' for the poor. On the other hand, abundance generates responsibility and generosity rather than extravagance and exultance. This combination makes life happy for everyone. Unfortunately, the so-called "Happiness Index" does not capture the sense of contentment generated by the trait of patience cultivated by Islamic teachings nor the joy generated by the trait of thankfulness to Allah Almighty for his bounties.

(8) OECD defines the "Gender Wage Gap" as the difference between median earnings of men and women relative to median earnings of men. 


\section{References}

Abu Dawood, Sulaiman bin Ashath (2009). Sunan Abi Dawood, Beirut: Dar al-Risalah al-Aalamiyyah. al-Bayhaqi, Ahmad bin al-Hussain. (2003). Shu'ab alImān [Branches of $\bar{\imath} m \bar{a} n$ ]. Riyadh: Maktabah al-Rushd.

Chapra, M. Umer. (2001). Prohibition of Interest: Does It Make Sense? Durban, South Africa: Islamic Da'wah Movement.

al-Bukhari, Muhammad bin Ismail. (1422H [2001]). Sahih al-Bukhari. Beirut: Dar Tawq al-Najah.

Ibn Taymiyyah, Ahmad bin Abdul Haleem. (n.d.). AlHisbah fi al-Islam. Beirut: Dar al-Kutub al-'Ilmiyyah.

Iqbal, Munawar (1988) Distributive Justice and Need Fulfillment in an Islamic Economy (ed.). Leicester, UK: The Islamic Foundation.

Kenway, P., \& Palmer, G. (2007). Poverty among ethnic groups: how and why does it differ? Homestead, UK: Joseph Rowntree Foundation. Retrieved from: www.poverty.org.uk/reports/ethnicity.pdf

al-Naisabouri, Muslim bin al-Hajjaj. (1991). Sahih Muslim. Beirut: Dar Ihya' al-Turath al-'Arabi.

al-Nasai, Ahmad bin Shoaib. (1986). Sunan al-Nasai. Aleppo, Syria: Maktab al-Matbo'at al-Islamiyyah.

Okun, A. Melvin. (1975). Equality and Efficiency: The Big Tradeoff. Washington, D.C.: Brookings Institution Press.
al-Shaibani, Ahmad bin Hanbal. (2001). Musnad alImam Ahmad bin Hanbal. Beirut: Mu'assasah AlRisalah.

Roser, M., \& Ortiz-Ospina, E. (2017). Global Extreme Poverty. Published online at OurWorldInData.org. Retrieved from: https://ourworldindata.org/extremepoverty/

Stein, Mark S. (2006). Distributive Justice and Disability: Utilitarianism against Egalitarianism. New Haven: Yale University Press.

al-Tirmidhi, Muhammad bin Eisa. (1975). Sunan alTirmidhi. Cairo: Makatabah wa Matba'ah Mustafa al-Babi al-Halabi.

Zaman, Asad. (2018). An Islamic Approach to Inequality and Poverty. Journal of King Abdulaziz University: Islamic Economics, 31(1), xx-xx.

Zarqa, M. Anas. (1988). Islamic Redistributive Schemes. In Munawar Iqbal (Ed.), Distributive Justice and Need Fulfilment in an Islamic Economy (pp. 163-216). Islamabad: International Institute of Islamic Economics, International Islamic University Islamabad. 
Munawar Iqbal [Ph.D. (1976) Simon Fraser University, Canada] is currently Professor at the Islamic Economics Institute, King Abdul Aziz University. In his long career spanning more than forty years, he has held many top positions. He served as Professor and Dean at the International Islamic University Islamabad (IIUI). He served as Chief of Research, Islamic Banking and Finance, at the Islamic Research and Training Institute (IRTI), Islamic Development Bank, Jeddah. Earlier, he served as the Founding Director, International Institute of Islamic Economics, International Islamic University (IIUI), Islamabad, Pakistan. He has taught at IIUI; McMaster and Simon Fraser Universities, Canada. He has authored/edited more than twenty-five books/ monographs. He has also published more than thirty papers. He was the founding Editor of the Review of Islamic Economics, and Islamic Economic Studies - the two most important journals in Islamic economics. He was founding Secretary General of the International Association of Islamic Economics (IAIE). Now he is advisor to the editorial board of the Journal of King Abdulaziz University: Islamic Economics, the only Scopus-listed journal in this field. His name has been included in Marquis Who's Who in the World.

E-mail: miqbal@kau.edu.sa; munawariqbal@gmail.com 


\title{
الفقر وعدم المساواة والتصهورات حول العدالة التوزيعية
}

\author{
منور إقبال \\ أستاذ، معهل الاقتصياد الإسلامي، جامعة الملك عبدالعنزيز، جلدة المبال
}

المستخلص. العدالة التوزيعية قد تعني أشياء مختلفة لمدارس الفكر المختلفة. المناقشات الراهنة حول الفقر وعدم المساواة هي من بين المناقشات الاقتصادية التي تجري منذ وقت طويل ولكنها تلقت اهتماما أكبر من قبل كل من الأكاديميين والسياسيين خلال السنوات الخمسين الماضية.

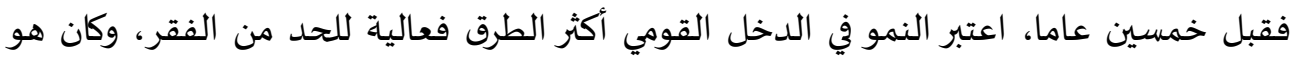

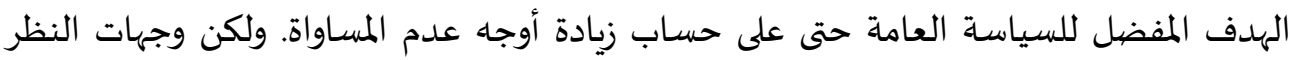

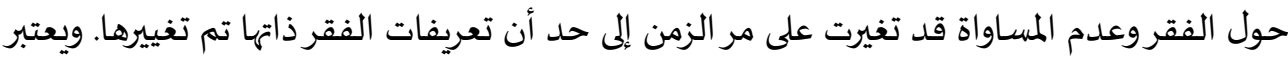

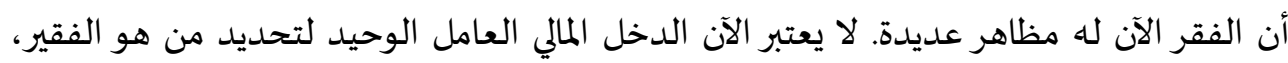

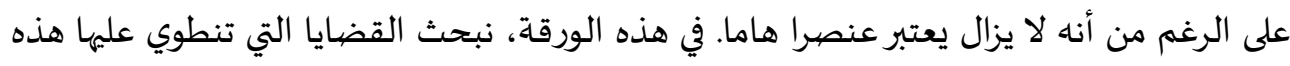


الإسلامي بشأن العدالة التوزيعية والاستراتيجية الإسلامية لتحقيقها. 